\title{
Implementation Of Enterprise Resource Planning In Business Curriculums
}

Brian D. Neureuther, (E-mail: sdbrian@isugw.indstate.edu), Indiana State University

\begin{abstract}
SAP, the most pervasive enterprise resource planning software package in the world, is currently being used in several universities across the US. The use of this software varies from institution to institution, primarily by the degree in which it permeates the business curriculum. From a personal perspective, the author seeks to examine why SAP is fully integrated in some curriculums and why it is sporadically used in other curriculums. The question of how SAP can be successfully implemented into the business curriculum is addressed and explained.
\end{abstract}

\section{INTRODUCTION}

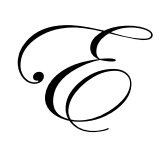

nterprise Resource Planning (ERP) systems are a prolific part of business today. Whether a firm uses the popular ERP package of SAP R/3 (further denoted simply as SAP) or they use another package such as Oracle, Microsoft, Peoplesoft, Baan, etc., their use is seen as paramount for many organizations. Because of this, many institution of higher education have been examining ways in which ERP packages can be used in the business curriculum. SAP was implemented into a College of Business' curriculum starting with California State University in 1996. Not far after that, several other universities have followed suit.

How far ERP systems are implemented into a curriculum depends on several factors. Several faculty members have discussed integrating ERP in the business school curriculum (see Fedorowicz et al. (2004), Johnson et al. (2004), Joseph and George (2002), Becerra-Fernandez et al. (2000), and Corbitt and Mensching (2000). Selen (2001) has developed a model in which business education is placed within the framework of demand chain management and supply networks. He places a large emphasis on the need to expose students to modern business ERP in order to establish learning in the new business school setting. Stewart and Rosemann (2001) design a problembased learning approach in an attempt to bring industrial knowledge into the curriculum using ERP software as a catalyst. They further design a curriculum based upon industry orientation. In a broader context, Hawking et al. (2004) developed five categories of curriculum development in ERP; ERP training, ERP via business processes, Information Systems approach, ERP concepts, and Hybrid.

In the field of Information Systems (IS), where ERP curriculum is most prevalent, Antonucci et al. (2004) define the ERP maturity model to assess ERP maturity levels. They do this in order to define where current Information Systems education is and where it needs to go according to its existing maturity level. There also exist several curriculum innovations in the filed of IS. For one example, Hajnal and Riordon (2004) describe a course in which they have implemented a case, titled petPro, into their course.

However, using SAP in business courses or functional areas (as previously discussed in the Information Systems field) and integrating ERP across the business curriculum are two distinct and separate issues. Many universities have implemented SAP in courses, but have either failed or have not been interested in integrating it throughout the curriculum. How should the implementation of SAP into the business curriculum take place? This question is addresses by examining the implementation of SAP into the Indiana State University's (ISU) business curriculum. It may be possible to achieve integration within a business curriculum by examining 1) the specific type of programs designed for ERP integration, 2) the fit to the College of Business' and University's missions, 3) support 
from administration for the program and support to faculty, 4) an appropriate implementation plan, 5) appropriate objectives and measures of success, and 6) appropriate levels of speed, training, and support.

\section{CHOOSING THE APPROPRIATE PROGRAM}

The program that ISU considered is called the SAP University Alliance program. The SAP University Alliance program is designed to incorporate the internationally recognized SAP enterprise software solutions into the College of Business' curriculum. SAP enterprise software links all functions within an organization together in an effort to track and manage, in real-time, sales, production, finance, accounting and human resources in an enterprise. Enterprise software creates just one information system in an enterprise so that all applications access common data and, in which, real events in the business initiate transactions. Accounting is done automatically by events in sales and production. Sales can see when products can be delivered. Production schedules are driven by sales. The whole system is designed to be real-time and not historical. The SAP University Alliance program offers a world-class ERP software package as well as training and curriculum support to the faculty.

\section{FIT / RATIONAL FOR COLLEGE AND UNIVERSITY}

One of the most important initial steps for the implementation was to ascertain that the initiative fit with the mission and strategic direction of not only the College of Business but the University at large. It was necessary to examine the rational for adoption and implementation as well as relate the rational to the strategy outlined at the University and College levels.

\section{Rational}

The purpose of examining the integration of the SAP software into the College of Business' curriculum was to successfully provide students with desirable business knowledge and skills to help them gain a competitive advantage when entering the job market. SAP software crosses all disciplines within the business curriculum and can be a valuable asset to the students in training and in hiring preference; eventually leading to enhanced student placement in a more geographically dispersed area.

In addition, the acquisition of SAP will enhance the reputation and image of the College of Business within the local and regional communities. It will help the College of Business make contacts in the local and regional community and may even lead to a network of training and education, activities that increase experiential opportunities for the students and faculty. The College of Business' exposure to the community will also be enhanced.

\section{FIT OF COLLEGE OF BUSINESS' MISSION}

In order for the integration to be successful it must match with the strategy of the College of Business and the University. For ISU, the College of Business has the following mission: "Our primary focus and commitment is to excellence in teaching. In tandem with this commitment faculty engage in applied and educational research, develop relationships with the business community, and provide services to the region and to their profession." By examining several issues that are discussed below, the fit of SAP integration and the synergies between SAP and the missions of the College can be clearly seen.

First, the commitment to teaching will be enhanced by the use of SAP in business courses. SAP can be used not only to demonstrate certain contextual issues in the classroom, such as the development of balance sheets and income statements, for example, but can then be used to demonstrate to the students how these contextual issues can be integrated into the entire firm. They will be able to see the impact that changes in these statements have on other areas of the firm and the decisions that these areas must make. This is truly an educational value that many business curriculums do not currently deliver. Therefore, the teaching pedagogy will be enhanced with the ability to better demonstrate contextual issues as well as being able to demonstrate the linkages across a business. 
Secondly, the use of SAP will enable the faculty to engage in applied and educational research by giving them the opportunity to work with SAP on grants. The SAP University Alliance Program offers grants for faculty actively engaged in developing curriculum that utilizes SAP. These grants can take the form of either applied research directly related to ERP implementation or educational research by developing curriculum suited for the SAP alliance.

Third, SAP implementation will enable additional contacts in industry, especially with firms in the local and surrounding community. The implementation will make these contacts more readily apparent and more easily fostered.

Finally, the SAP initiative will enable business faculty to provide service to the profession by using a new tool with which they can attend new conferences and present research. This research can take two forms. The first form is applied or theoretical research on ERP in general. The second form is based on educational research for curriculum issues dealing with the implementation of the SAP software in the classroom. This research will enable all faculty in the business curriculum to have a greater presence at academic conferences normally attended as well have a presence at academic conferences that are normally not attended.

\section{Indiana State University Fit}

One of the major purposes of acquiring a license for the SAP software was to successfully provide students with desirable business knowledge and skills to help them gain a competitive advantage when entering the job market. This would enhance the placement of students and will eventually lead to an increase in enrollment as prospective students become aware of this opportunity. SAP software crosses all disciplines within the business curriculum and can be a valuable asset to students in training and in hiring preference.

Another advantage was that software hosting was included with the membership fee. With hosting, the business curriculum could begin utilizing the SAP enterprise software solutions almost immediately and focus on curriculum development and implementation instead of acting as a systems administrator. A SAP University Competence Center (UCC) administers the software, alleviating the need for any full-time administrator and allowing learning to be put first. Universities that are trained in the administration of SAP (and approved by the Alliance Program) and SAP's various components are called UCC's. Software hosting, therefore, will not tie up faculty resources at the implementing university. These two issues focus on the human resource dimension; giving the faculty something that they want and can incorporate into their existing curriculums while not using faculty resources for administration, support, and maintenance the software.

\section{SUPPORT}

In addition to examining the strategic implication of the SAP initiative, the need to determine what support would be received at the onset of the implementation became clear. Without commitment from faculty, college administration and university administration the effectiveness of the implementation would be suspect. Therefore, the support from three different perspectives was examined: the administration of the College of Business, the administration of the University, and the College of Business faculty.

\section{Support of College and University Administration}

Ever since the initial mention of the possibility of having SAP software for use in the classroom, the Dean has been a staunch supporter. Included with this support is support from the Associate Dean of Undergraduate Programs as well as the Chairmen of the Analytical and Organizational Departments. In short, the full support of the entire top administration in the College of Business was in hand. In addition, there was the support of many program chairs within the College of Business, including program chairs from Operations Management and Analysis (OMA), Management Information Systems (MIS), Accounting (ACCT), Management (MGT), Insurance and Risk, and Business Education, Information, and Technology (BEIT). Finally, several faculty members were interested, at some point, in using the SAP software. These faculty members span all functional areas in the College of Business. 
Another great area of support is on the monetary side. With a 4 year $\$ 20$ million Lilly Foundation grant, the necessary funds were available which could be used for the implementation of this software. Monies from this grant have already worked their way into this initiative by means of conference attendance (SAP Innovation Congress), by the acquisition of the software itself, and by the investment in the state of the art computer lab. These funds will further be used for faculty training workshops offered through the SAP University Alliance program as well for future SAP conference attendance.

In addition, the administration has been supportive in yet another dimension, that of release time for the development of the curriculum plan and software acquisition. Further release time for the implementation of the software and for faculty training initiatives may be in the future as well. This release time is an important sign of the support generated.

Finally, beyond the College of Business, the University President and the Provost (the two top positions in a university environment) have expresses their support. Therefore, not only is there considerable financial support, but there is also a great deal of support from the administration and faculty.

\section{Support of College of Business Faculty}

Assessing support of the faculty was accomplished by speaking with Department Chairs and Program Coordinators. It was important that as many of these individuals as possible be convinced of the necessity to implement SAP into the curriculum. Therefore, several avenues must be pursued to garnish sustainable interest. For example, the faculty will have access to training opportunities through SAP University Alliance curriculum workshops and SAP standard training courses, technical support, curriculum support, access to the SAP University Alliance faculty network and curriculum materials, and curriculum and research funding opportunities. This program is not only good for the students, but it's an excellent opportunity for the faculty to grow professionally, complete research, and obtain additional monies through research and curriculum grants offered through SAP. All of these advantages are key selling points for getting various faculty involved; as each may have a different motivation depending upon where they are in their academic career.

\section{OBJECTIVES AND MEASUREMENT}

Clear objectives and clear mechanisms for measurements were next identified in order to evaluate the success of the implementation. This is an important, but frequently overlooked, aspect of any implementation plan. The objectives of the integration were divided into two primary stakeholders, the students and the College of Business. It was important to assess what was the main purpose of implementation.

\section{Objectives}

The following objectives with respect to the integration of SAP in the business curriculum were developed. The objectives have been broken down into two different perspectives; those of the student's and those of the College of Business'.

\section{Student Perspective}

1. To give all business student hands on experience with an ERP software package.

2. To demonstrate to students what an ERP software package is and what it can do for a business' long term competitive advantage.

3. To educate students, in general, on ERP solutions.

4. To increase a students general knowledge on the integration of information in businesses.

5. To improve a students attractiveness to the business world upon leaving ISU. 


\section{School of Business Perspective}

1. To increase enrollments in the College of Business.

2. To increase the College of Business' presence in the local and regional community.

3. To bring the College of Business more in line with current industry trends and advances.

\section{Measurements}

In order to gauge whether or not the SAP University Alliance Program is meeting these objectives, the following constructs were used to monitor the process, beginning in January of 2004 for the base line measurements. These constructs are not an exhaustive list, but a relatively simple list of only those constructs necessary to identify areas for improvement with the implementation of the program.

1. Student knowledge of functional integration

2. Enrollment rates for OM, MIS and BEIT courses and majors

3. Enrollment rates of the School of Business in general

4. Recruitment rates of OM, MIS and BEIT graduates

5. Starting salaries for OM, MIS and BEIT graduates

In addition to using these constructs as valuable assessment tools, it is believed that the information gathered from these tools can then be used for faculty to engage in applied and theoretical research.

\section{BASIC IMPLEMENTATION PLAN}

Because implementation of this software is a large task and because of internal business polices, SAP was initially used in a few courses over a few programs. The goal was for these areas to become well versed in SAP so that they could then become training centers for other programs. A slow, but methodical migration of the courses into the curriculum was planned. It is also worth noting that, initially, the SAP software was restricted to courses that were in individual program majors, and not for courses that were part of the business core. Due to university policies and standards, if the software was to be used pervasively in the core business curriculum, the issue would have to go through the appropriate university committee structure - something that is never a guarantee.

\section{SUMMARY/CONCLUSION}

There is still work to be done in order to make SAP truly integrated in the business curriculum. SAP was initially used in upper level courses and will be used in the first business core course (courses that all business majors are required to take) in the fall of 2005. It is also anticipated that, at some point, a required course as an introduction to SAP will be planned. Currently SAP is utilized in several key areas including Operations Management, Business Education, Management Information Systems, and Accounting Information Systems. Over twenty of the forty-five or so faculty are been trained in the introduction to SAP and five or more have attended advanced courses in their areas of expertise.

\section{REFERENCES}

1. Antonucci, Yvonne Lederer, Gail Corbitt, Glenn Stewart, and Albert L. Harris, (2004). Enterprise systems education: where are we? Where are we going? Journal of Information Systems Education, vol. 15, no. 3, pp. 227-234.

2. Becerra-Fernandez Irma, Kenneth E. Murphy and Steven J. Simon, 2000. Integrating ERP in the business school curriculum. Association for Computing Machinery. Communications of the ACM, vol. 43, no. 4, pp. 39-41.

3. Corbitt, Gail and James Mensching, 2000. Integrating SAP R/3 into a college of business curriculum: Lessons learned. Information Technology and Management, vol. 1, no. 4. pp. 247-258. 
4. Fedorowicz, Jane, Ulic J. Gelinas Jr., Catherine Usoff, and George Hachey, 2004. Twelve tips for successfully integrating enterprise systems across the curriculum. Journal of Information Systems Education, vol. 15 , no. 3 , pp. $235-244$.

5. Hajnal, Catherine A. and Robert Riordan, 2004. Exploring process, enterprise integration and e-business concepts in the classroom: The case of petPro. Journal of Information Systems Education, vol. 15, no. 3, pp. 267-275.

6. Hawking, Paul, Brendan McCarthy and Andrew Stein, 2004. Second wave ERP education. Journal of Information Systems Education, vol. 15, no. 3, pp. 327-332.

7. Johnson, Todd, Alden C. Lorents, James Morgan, and Jon Ozmun, 2004. A customized ERP/SAP model for business curriculum integration. Journal of Information Systems Education, vol. 15, no. 3, pp. 245-253.

8. Joseph, George and Asha George, 2002. ERP, learning communities, and curriculum integration. Journal of Information System Education, vol. 13, no. 1. pp. 51-58.

9. Selen, William, 2001. Learning in the new business school setting: A collaborative model. The Learning Organization, vol. 8, no. 3/4, pp. 106.

10. Stewart, G. and M. Rosemann, 2001. Industry-oriented design of ERP-related curriculum - an Australian initiative. Business Process Management Journal, vol. 7, no. 3, pp. 234-242. 